\title{
Geochelone platynota (Blyth 1863) - Burmese Star Tortoise, Kye Leik
}

\author{
Steven G. Platt ${ }^{1}$, Thanda Swe ${ }^{2}$, Win Ko Ko ${ }^{1}$, Kalyar Platt ${ }^{3}$, \\ Khin Myo Myo ${ }^{1}$, Thomas R. Rainwater ${ }^{4}$, ANd David EMmetT $^{5}$ \\ ${ }^{1}$ Wildlife Conservation Society, Myanmar Program, \\ Aye Yeik Mon 1st Street, Yadanamon Hosuing Ave., Yangon, Myanmar \\ [sgplatt@gmail.com,khinmyomyo_wcs@myanmar.com.mm]; \\ ${ }^{2}$ Zoology Department, Yadanabon University, Mandalay, Myanmar; \\ ${ }^{3}$ Turtle Survival Alliance, Aye Yeik Mon 1st Street, Yadanamon Hosuing Ave., \\ Yangon, Myanmar [kalyarplatt@gmail.com]; \\ ${ }^{4}$ Department of Obstetrics and Gynecology, Medical University of South Carolina, \\ Hollings Marine Laboratory, Charleston, South Carolina, 29412,USA [trrainwater@gmail.com]; \\ ${ }^{5}$ Conservation International, Indo-Burma Program, \#10 Street 420 , \\ Phnom Penh,Cambodia [d.emmett@conservation.org]
}

\begin{abstract}
Summary. - The Burmese Star Tortoise, Geochelone platynota (Family Testudinidae) is a medium-sized tortoise (carapace length to ca. $30 \mathrm{~cm}$ ) endemic to the dry zone of central Myanmar. Little is known concerning the ecology of G. platynota in the wild. The species occurs in xerophytic habitats typical of the dry zone, as well as grazed pastures, hedgerows, and agricultural fields. Its diet consists largely of grass and other vegetation, but fruit, mushrooms, snails, and insect remains have been recovered in feces. Mating occurs from June to September, followed by egg-laying from October through February. The mean size of 27 clutches was 4.4 eggs, and a positive relationship was noted between female size and clutch size. Based on a limited sample, the home range of males is somewhat larger than that of females. During cool and dry periods, activity declined and tortoises sheltered in bamboo thickets, undercut banks, and rock crevices. Geochelone platynota occurs both macro- and microsympatrically with Indotestudo elongata in the dry zone, but the ecological relationship between the two species remains poorly understood. The few available data suggest that $G$. platynota is ecologically extinct in the wild, as a result of historic long-term subsistence harvesting and more recent over-collecting to supply illegal international food and pet markets. The last known wild populations in Shwe Settaw and Minzontaung Wildlife Sanctuaries, and Myaleik Taung are now apparently reduced to non-viable levels. Future conservation efforts hinge on developing and implementing successful captive breeding and reintroduction programs in Myanmar. Currently, offspring are being produced at several rearing facilities in Myanmar, but persistent rampant poaching precludes the reintroduction of tortoises into protected areas.

Distribution. - Myanmar. Endemic to the dry zone of central Myanmar (Burma).

Synonomy. - Testudo platynota Blyth 1863, Peltastes platynotus, Geochelone platynota, Geochelone elegans platynota.

SubSPECIES. - None.

STATUS. - IUCN 2011 Red List: Critically Endangered (CR A1cd+2cd, C2a) (assessed 2000); CITES: Appendix II, as Testudinidae spp.; Myanmar: Protection of Wildlife, Wild Plants and Conservation of Natural Areas Law: Protected.
\end{abstract}

Taxonomy. - The Burmese Star Tortoise, Geochelone platynota, family Testudinidae, was originally described as Testudo platynota (Blyth 1863), and reviewed by Smith (1931) and Bourret (1941). Loveridge and Williams (1957) restricted Testudo to five species of Palearctic tortoises, with those from other zoogeographic regions being assigned to different genera; many large-bodied tropical species, including T. platynota were transferred to the genus Geochelone. Obst (1986) considered G. platynota to be a subspecies of G. elegans without justification (Iverson 1992). Le et al. (2006) concluded Geochelone was a polyphyletic genus with species distributed in four independent clades; G. platynota was placed in the G. elegans group that also included $G$. elegans and G. sulcata (a species now sometimes referred to the monotypic genus Centrochelys). Further analysis by Fritz and Bininda-Edmonds (2007) has supported this grouping. The clade containing G. platynota is thought to have originated in Africa and later dispersed into Asia (Le at al. 2006). Geochelone platynota is known locally in Myanmar as Kye Leik, which literally translates to "star turtle", and refers to the striking patterns on the carapace and plastron.

Description. - Geochelone platynota is a mediumsized tortoise with a carapace length (CL) to at least 30 $\mathrm{cm}$; females are larger than males $(\mathrm{CL} \leq 25 \mathrm{~cm}$ ) (Platt et al. 


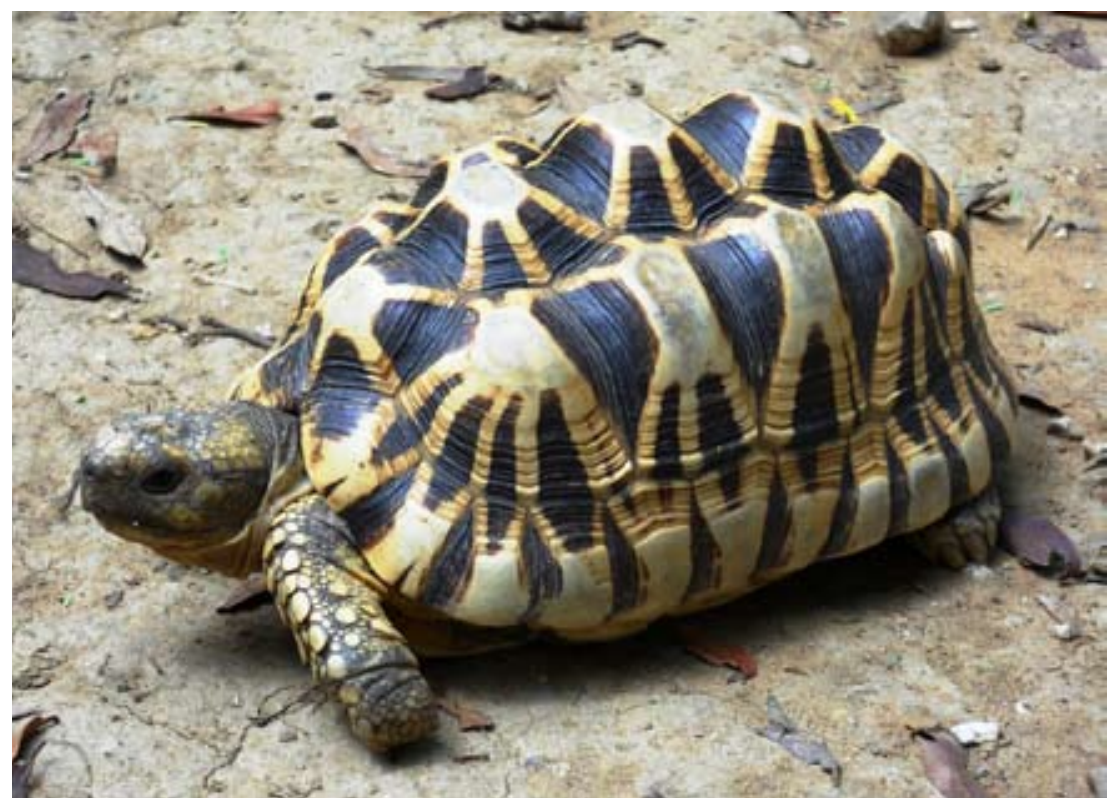

Figure 1. Adult Geochelone platynota at Lawkanandar Wildlife Sanctury in Bagan. Photo by Kalyar Platt.

2003). Descriptions are provided by Smith (1931) and Ernst and Barbour (1989).

The carapace is convex, but flattened dorsally with a slight cervical indentation. The posterior marginals are somewhat expanded, but weakly serrated; the nuchal scute is absent. The first vertebral scute is longer than broad, and vertebrals 2 to 5 are broader than long; vertebral 5 is expanded and 4 is relatively small. There are usually 11 marginals on each side; the supracaudal scute is undivided and curves downward. The carapace is light brown to black with six or fewer stripes radiating from the yellow areola

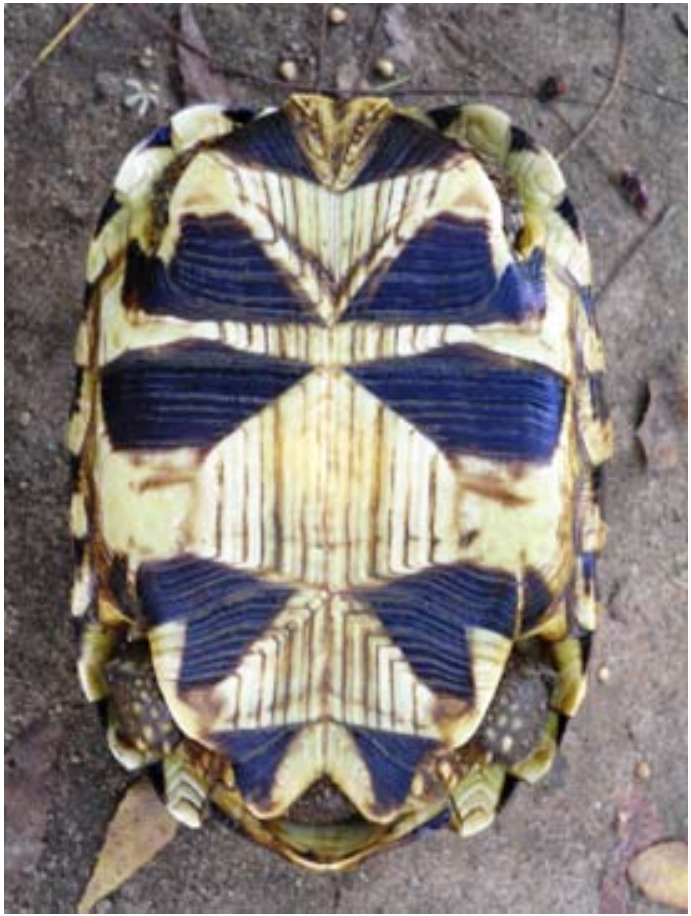

Figure 2. Adult Geochelone platynota at Lawkanandar Wildlife Sanctury in Bagan. Photo by Kalyar Platt. of each vertebral and pleural scute. Each marginal has two yellow stripes that form a $\mathrm{V}$.

The plastron is notched both anteriorly and posteriorly; the forelobe is narrower, but longer than the hind lobe. The plastral formula is abdominal $>$ humeral $>$ femoral $>$ gular $>$ anal $>$ pectoral. The bridge is wide and the axillary scute is smaller than the inguinal scute.

The head is moderate-sized with a weakly hooked, feebly tricuspid lower jaw. A large prefrontal is divided longitudinally and followed by a single large frontal scale; the remaining head scales are small. The skin of the head,

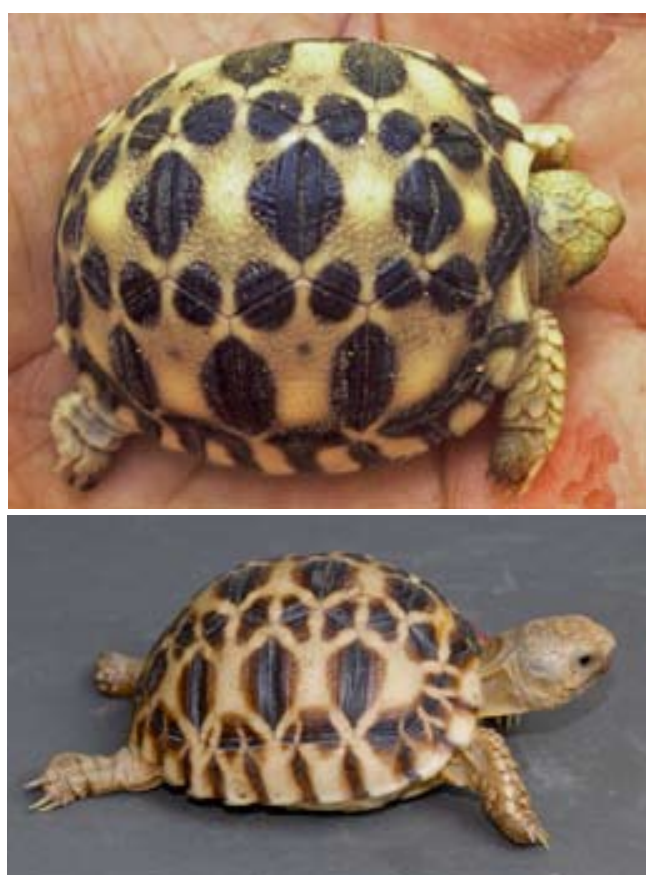

Figure 3. Captive-bred juvenile Geochelone platynota at Shwe Settaw Wildlife Sanctuary. Photos by Kalyar Platt (top) and Peter Paul van Dijk (bottom). 


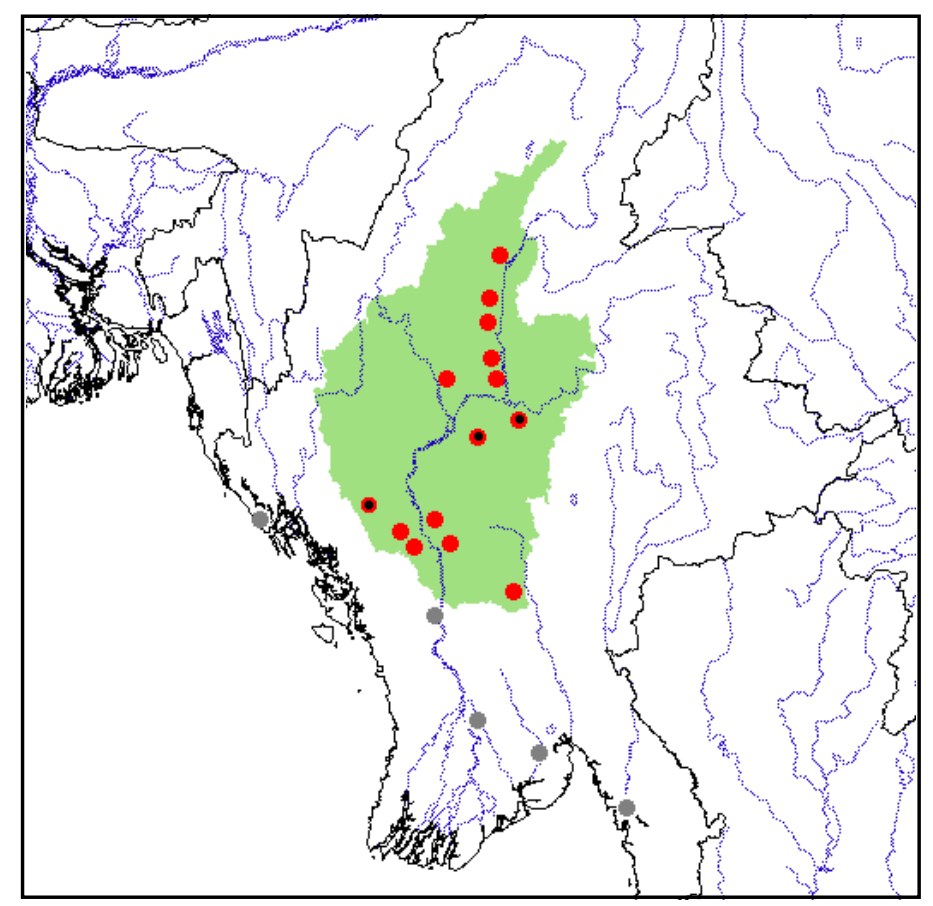

Figure 4. Distribution of Geochelone platynota in central Myanmar. Red dots = museum and literature occurrence records of historical populations based on historical and authors' data, now all most likely extirpated; gray dots = market specimens or possible previous occurrence records mapped by Iverson (1992); red / black dots = last three known wild populations at Shwe Settaw and Minzontaung Wildlife Sanctuaries and Myaleik Taung, now also largely extirpated; green shading = projected original native distribution based on GIS-defined hydrologic unit compartments (HUCs) constructed around verified localities and then adding HUCs that connect known point localities in the same watershed or physiographic region, and similar habitats and elevations as verified HUCs (Buhlmann et al. 2009), and adjusted based on authors' data.

limbs, and tail is yellowish. The anterior surface of the forelimbs is covered with heavy, rounded scales. The tail terminates with a spur-like tubercle. Males are distinguished by a prominent plastral concavity that is absent in females, and longer, thicker tails with the vent more distal, close to the tip.

Distribution. - Geochelone platynota is endemic to the dry zone of central Myanmar (Burma); however, within this region its distribution remains ill-defined and few specimen-based locality records are available (Platt et al. 2004). Early records of $G$. platynota from localities outside

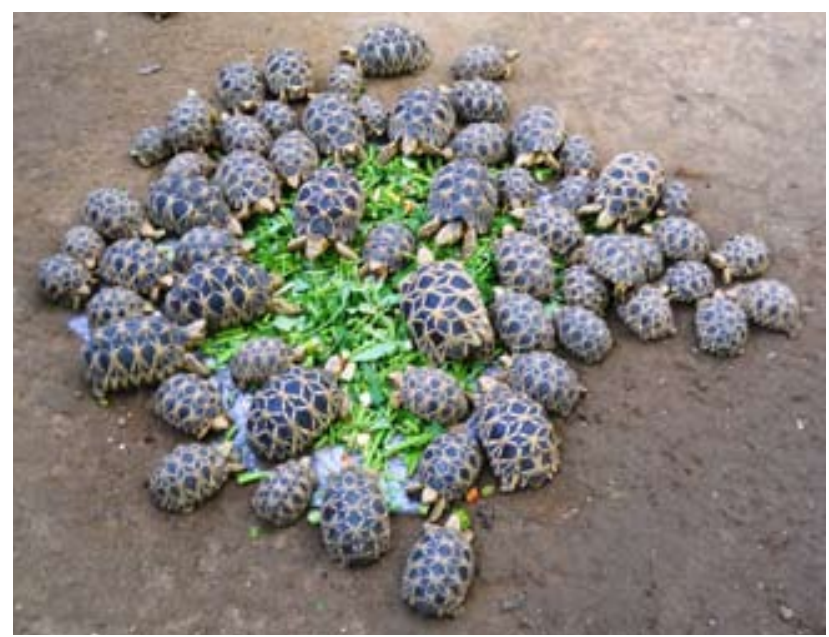

Figure 5. Captive Geochelone platynota at Shweponetaung Farm in Nyaung Oo. Photo by Kalyar Platt. of the dry zone such as Moulmein (Mawlamyine), Rangoon (Yangon), and Pegu (Bago) (Blyth 1863; Theobald 1868; Smith 1931), are based on specimens obtained in markets and probably not reflective of the natural distribution (van Dijk 1993). A reference by Abreu (1858) to Testudo radiata, a Madagascan species with a carapace pattern similar to $G$. platynota, encountered north of Toungoo $\left(18^{\circ} 53^{\prime} \mathrm{N} ; 96^{\circ} 23^{\prime} \mathrm{E}\right)$ is probably assignable to the latter. A G. platynota in the collection of the Zoological Society of India (ZSI 17049) was collected near Yenangyoung $\left(20^{\circ} 27^{\prime} \mathrm{N}\right.$; 94 $\left.4^{\circ} 52^{\prime} \mathrm{E}\right)$ during the 1920s (Indraneil Das, pers. comm.), and Iverson (1992) reported another from Magwe $\left(20^{\circ} 08^{\prime} \mathrm{N}\right.$; 94 $\left.94^{\circ} \mathrm{T} \mathrm{E}\right)$.

More recently $G$. platynota has been reported from Shwe Settaw $\left(20^{\circ} 11^{\prime} \mathrm{N} ; 94^{\circ} 28^{\prime} \mathrm{E}\right)$ and Minzontaung $\left(21^{\circ} 24^{\prime} \mathrm{N} ; 95^{\circ} 47^{\prime} \mathrm{E}\right)$ Wildlife Sanctuaries, and Myaleik Taung (21 ${ }^{\circ} 47^{\prime} \mathrm{N}$; $\left.96^{\circ} 15^{\prime} \mathrm{E}\right)$ (van Dijk 1993; Platt et al.2001a, 2003). Additional specimens of $G$. platynota have been reported from scattered localities in the dry zone, including Hti Chaing Town $\left(23^{\circ} 44.8^{\prime} \mathrm{N} ; 96^{\circ} 08.9 \mathrm{E}\right)$, and Myinthar-Kyarnyut $\left(23^{\circ} 14.5^{\prime} \mathrm{N}\right.$; 95 $\left.95^{\circ} 9.4^{\prime} \mathrm{E}\right)$, Mau $\left(22^{\circ} 40.7^{\prime} \mathrm{N}\right.$; 95 $\left.95^{\circ} 543^{\prime} \mathrm{E}\right)$, Budalin $\left(22^{\circ} 25.1^{\prime} \mathrm{N}\right.$; $\left.95^{\circ} 10.0^{\prime} \mathrm{E}\right)$, Sheinmaga $\left(22^{\circ} 16.8^{\prime} \mathrm{N}\right.$;

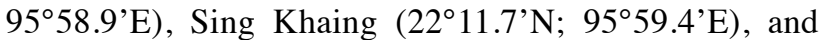
Padan $\left(20^{\circ} 00.0^{\prime} \mathrm{N}\right.$; $\left.94^{\circ} 31.2^{\prime} \mathrm{E}\right)$ villages; these tortoises were reportedly collected nearby (Platt 2001a; Platt et al. 2004).

Specimens from Hti Chaing Town constitute the northernmost records of G. platynota in Myanmar (Platt et al. 2004). Geochelone platynota is also thought to occur in the Sagaing Hills on the northwestern periphery of the dry 


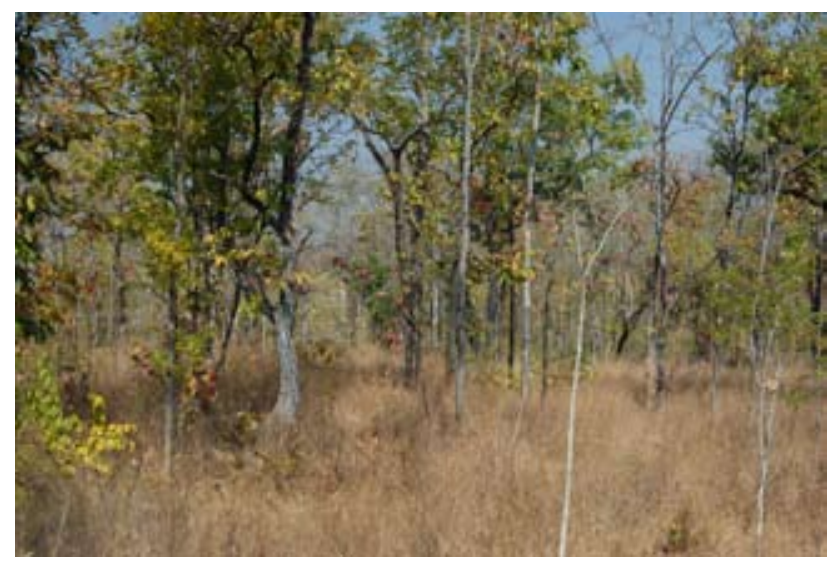

Figure 6. Typical habitat of Geochelone platynota in dry central Myanmar, Shwe Settaw Wildlife Sanctuary, January 2009. Photo by Peter Paul van Dijk.

zone, although this remains to be verified (Platt et al. 2004). Geochelone platynota has not been found in Chattin Wildlife Sanctuary despite an intensive search of apparently suitable habitat (Zug et al. 1998).

Habitat and Ecology. - Historically, G. platynota probably occurred throughout the dry zone of central Myanmar. The dry zone is a semi-arid region formed by the rain shadow of the Chin Hills and Rakhine Yoma Mountains of western Myanmar (Roberts et al. 1968). This region experiences a tropical monsoonal climate with a wet season extending from late June through September followed by a prolonged dry season from October through mid-June (de Terra 1944).Annual precipitation in the dry zone ranges from 500 to $1000 \mathrm{~mm}$. High diurnal (maximum $=43^{\circ} \mathrm{C}$ ) and low nocturnal (minimum $=4^{\circ} \mathrm{C}$ ) temperatures occur during the dry and wet seasons, respectively (FAO/UNDP 1982).

The vegetation typical of $G$. platynota habitat has been variously described as thorn forest and thorn scrub (Stamp and Lord 1923), dry forest (Hundley 1961), dry deciduous forest (FAO/UNDP 1982), and semi-desert scrub (Davis 1964). Regardless of the classification system, these vegetative associations are characterized by xerophytic and fire-resistant species such as Acacia spp., Dipterocarpus tuberculatus, Tectona hamiltoniana, Terminalia oliveri, and Euphorbia spp., with an understory of various grasses. Extensive bamboo (Bambusa tulda, Dendrocalamus strictus) brakes are common in many areas of the dry zone (Searle 1928). Pristine habitats are not required by G. platynota; when not exploited, star tortoises inhabit grazed pastures, scrub/field ecotones, hedgerows, and agricultural fields in the dry zone (Platt 2001a, 2001b; Platt et al. 2003).

Little is known regarding the ecology of wild populations of G.platynota (Moll 1989; van Dijk 1997; Platt et al.2000). The feces of four G. platynota captured in Shwe Settaw Wildlife Sanctuary contained grass, unidentified plant material, insect chitin, and small stones; the latter may facilitate digestion of plant material (Platt et al. 2001a). The feces of two G. platynota captured at Myaleik Taung near Mandalay consisted mostly of grass, but seeds of
Cassia sp. and an unidentified vine were also found (Platt 2001b). Thanda Swe (2004) observed wild G. platynota consuming snails (Valvata helicoidea), unidentified mosses and fungi, and the foliage of Commerlina benghalensis, Terminalia oliveri, and Cyanotis axillaris at Minzontaung Wildlife Sanctuary. Captive tortoises in a large semi-natural enclosure at the sanctuary were observed consuming earthworms and millipedes, particularly at dawn and dusk when these invertebrates are most active (D. Emmett, pers. obs.). According to hunters, G. platynota feeds heavily on grass sprouts, especially at the beginning of the wet season. Other foods commonly consumed include the fallen flowers of Dolichandrone spathacea, Millettia brandisiana, and Markhamia stipulata, fruits of Olax scandens, and flowers and foliage of Allium spp (Platt et al. 2001a). Hunters also found tortoises consuming eggshells from Red Junglefowl (Gallus gallus) nests after hatching (Platt et al. 2001a). Hunters reportedly use rancid meat to trap G. platynota and captives at the Yadanabon Zoological Gardens have been observed eating dead Vipera russelli tossed into their enclosure (Thanda Swe 2004), suggesting carrion is an occasional food source among wild populations.

The reproductive ecology of wild G. platynota remains virtually unknown (Platt et al. 2001a). Smith (1931) stated that a clutch of eggs, "few in number" and each measuring approximately $40 \mathrm{~mm}$ wide $\times 55 \mathrm{~mm}$ long, is deposited at the end of February. Platt et al. (2001a) examined six hatchlings held in an enclosure at Shwe Settaw Wildlife Sanctuary that were collected from a nest in May. The nest was excavated in heavy clay soil and found in a ridgetop clearing surrounded by open Tectona hamiltoniana forest. When found the neonates had already emerged from the egg, but were still in the nest cavity. It is possible hatchlings emerge from the egg but remain in the nest cavity until the onset of the wet season when conditions might be more favorable for survival (Platt et al. 2001a).

Thanda Swe (2004) studied reproduction among captive groups of G. platynota held in semi-natural enclosures at several locations in the dry zone. Mating behavior was first noted during June and continued through September. Immediately prior to copulation, males trailed females for approximately 30 minutes. During coitus, males uttered grunts that were audible to researchers. Egg-laying occurred during the dry season, from 11 October through 25 February. Clutches were deposited in a shallow hole (approximately $14 \mathrm{~cm}$ deep $\times 15 \mathrm{~cm}$ wide $\times 9 \mathrm{~cm}$ long). The mean $( \pm 1 \mathrm{SE})$ number of eggs in 27 clutches was $4.4 \pm 0.4$ (range $=1$ to 11 ), and females deposited 1 to 4 clutches each breeding season. A significant positive correlation was noted between carapace length of the female and clutch size $\left(r^{2}=0.42 ; n=12 ; F=7.53, p=0.02\right)$. The total number of eggs deposited by a single female during one breeding season ranged from 7 to $16(\mathrm{n}=11)$. The mean $( \pm 1$ SE) incubation period for 7 clutches incubated under natural conditions was $197 \pm 9.9$ days (range $=172$ to 251 days). Hatching occurred between 6 May and 29 July, a period coinciding with the onset of the wet season. 
Based on a limited sample of $G$. platynota in Minzontaung Wildlife Sanctuary, Thanda Swe (2004) found the home range of two males was somewhat larger $\left(2.0\right.$ and $\left.1.9 \mathrm{~km}^{2}\right)$ than that of two females $(1.6$ and 0.6 $\mathrm{km} 2$ ). Tortoise movements increased in response to rainfall, and as a result the home range of both sexes increased during the wet season. Regardless of season, males made greater daily movements in comparison to females. In some cases tortoises moved relatively great distances over brief periods. For example, an adult male at Shwe Settaw Wildlife Sanctuary moved $1.48 \mathrm{~km}$ (straight-line distance) from where it was released only $48 \mathrm{hrs}$ earlier (Platt et al. 2001a). During cool and dry periods of the year, activity declined and tortoises sheltered in bamboo thickets, dense scrub, undercut banks, and crevices among rocks.

Geochelone platynota occurs both macro- and microsympatrically with Indotestudo elongata (Platt 2001b; Platt et al. 2001a, 2003) and possibly Manouria emys (Platt et al. 2001b) in the dry zone. The ecological relationship between G. platynota and I. elongata has not been studied and remains poorly understood (Platt et al. 2001a). Theobald (1868) stated that local hunters captured G. platynota and I. elongata by burning "grass jungles and forest". Moll (1989) noted it was unclear from this early account if both species occurred in each habitat, or if one was restricted to grasslands and the other to forests. Indotestudo elongata was absent from agricultural lands at Myaleik Taung (Platt 2001b), but no other evidence of habitat partitioning by $G$. platynota or I.elongata was found at Myaleik Taung or Shwe Settaw and Minzontaung Wildlife Sanctuaries. Captures of both species occurred in the same general area, and in a variety of microhabitats including bamboo thickets, wooded slopes, and open grasslands (Platt 2001b; Platt et al. 2001a). At Shew Settaw Wildlife Sanctuary and Myaleik Taung, $G$. platynota and I. elongata were occasionally captured only a few meters apart (Platt 1999, 2001b; Platt et al. 2001a). At Shwe Settaw Wildlife Sanctuary both species of tortoise were found to be infected with ticks (Amblyomma clypeolatum); otherwise nothing is known regarding parasites of wild $G$. platynota (Robbins and Platt 2000).

Population Status. - The few available population data suggest G.platynota is ecologically extinct in the wild, largely as the result of historic long-term subsistence harvesting and more recent over-collection to supply international food and pet markets (see Threats to Survival below).

As early as the 1980s, Crumly (1982) speculated that G.platynota was probably extinct owing to the difficulty of obtaining specimens for study. However, surveys in 1994 and 1999 found a small number of G. platynota persisting in Shwe Settaw Wildlife Sanctuary (van Dijk 1994; Platt et al. 2001a), although this population was hunted to nearextinction shortly thereafter (Platt 2001c; Platt et al. 2003; Platt et al. 2011).

By 2000 the only known viable populations of $G$. platynota in Myanmar occurred in Minzontaung Wildlife Sanctuary and Myaleik Taung (Platt et al. 2003). The survival of G. platynota at Myaleik Taung, and to a lesser extent Minzontaung Wildlife Sanctuary, was attributed to the protection conferred by local religious beliefs (Platt et al. 2003). Villagers believed that nats (= spirits) residing in nearby mountains protected the tortoises, and anyone harming or even disturbing a tortoise would face supernatural retribution. Myaleik Taung harbored the least disturbed and most significant G. platynota population ever identified in Myanmar, and plans were made to designate this area as a National Star Tortoise Sanctuary (Platt et al. 2003).

However, before a sanctuary could be established, collectors from outside the area arrived and rapidly decimated the population (Win Ko Ko, unpubl. data). Likewise, commercial collectors began operating in Minzontaung Wildlife Sanctuary at about the same time, and within a brief period reduced tortoise populations to very low levels (Thanda Swe 2004). This is best illustrated by the search effort necessary to locate tortoises in the sanctuary: 239 manhours and $27 \mathrm{dog}$-hours were required to find one tortoise in early 2001 (Platt 2001b; Platt et al. 2003), but by 2002-03 this had increased to 975 man-hours and 281 dog-hours (Thanda Swe 2004), suggesting a dramatic decline in the G. platynota population.

As a result of this surge in illegal harvesting, viable populations of G. platynota are no longer thought to exist at either Myaleik Taung or Minzontaung Wildlife Sanctuary (Win Ko Ko, unpubl. data). Undoubtedly, scattered individuals survive elsewhere in the dry zone, but without exception villagers now regard G.platynota as "uncommon" or "rare" (Platt et al.2004). Because the dry zone is a densely populated agricultural landscape (Roberts et al. 1968) and subsistence and commercial harvesting are ubiquitous throughout the region, we consider it unlikely that viable wild populations of G. platynota remain in Myanmar.

Threats to Survival. - Over-harvesting for subsistence and commercial purposes is regarded as the single most important threat to the continued survival of G. platynota in the wild in Myanmar (Platt et al. 2000). Rural Burmese have long exploited G. platynota for food (Klemens and Thorbjarnarson 1995). Theobald (1868) stated that large numbers were captured with the aid of dogs, and according to Blythe (1863), specimens were difficult to obtain because villagers were "so fond of eating them".

In Shwe Settaw Wildlife Sanctuary, subsistence harvesting was largely opportunistic; tortoises were collected when villagers entered the sanctuary to cut bamboo, herd cattle, and collect fuelwood (Platt et al. 2001a). Moreover, subsistence harvesters primarily targeted adults, and smaller tortoises were rarely taken (Platt et al. 2001a). Nonetheless, like most chelonians, tortoise populations cannot withstand even low to moderate levels of harvest of adults (Congdon et al. 1993), and it is doubtful whether any harvest can be considered truly sustainable (Thorbjarnarson et al. 2000). Because central Myanmar has supported dense human populations for over 1000 years (Thant Myint-U 2006), it is probable that subsistence harvesting eliminated G. platynota from many areas of the dry zone well before recent times. 
Harvesting dramatically increased and ceased to be a local subsistence activity in the mid-1990s when traders began purchasing tortoises for export to wildlife markets in southern China (Platt et al. 2000, 2001a). This period coincides with a massive increase in the harvest of wild chelonians throughout Southeast Asia to supply burgeoning Chinese wildlife markets (Jenkins 1995; van Dijk et al. 2000; Compton 2000). This trade begins when village-level dealers purchase tortoises and other wildlife from locals, and in turn sell to middlemen based in larger cities, particularly Mandalay, who then smuggle wildlife northwards to markets in southern China. Juveniles and small adult G. platynota are in especially high demand for the pet trade, while some larger adults enter food or medicinal markets (Das 1997; Platt et al. 2000, 2001a).

Because of its illicit nature, the commercial trade in G. platynota is extremely difficult to accurately quantify, but there is little doubt that vast numbers of tortoises were removed from the wild over the last decade. At the local level, many engaged in the trade were professional hunters who obtained most of their livelihood from the sale of wildlife (Platt et al. 2001a). The use of hunting dogs, an extremely efficient means of finding tortoises (Platt et al. 2003) was widespread among this group, and allowed hunters to methodically strip entire regions of tortoises (Platt et al. 2001a). For example, one hunter near Shwe Settaw Wildlife Sanctuary claimed to have taken about $300 \mathrm{G}$. platynota in 1999 , and another stated that it was possible to catch two to three tortoises each day during the early wet season (Platt et al. 2001a). Each village seemed to have several people actively engaged in hunting tortoises in addition to most villagers who collected tortoises in an opportunistic fashion (Platt et al.2001a). Even within protected areas G. platynota was subjected to harvest as the demise of populations at Shwe Settaw and Minzontaung Wildlife Sanctuaries attest (van Dijk 1994; Platt et al. 2001a; Thanda Swe 2004). Although harvesting has declined dramatically in recent years owing to the extirpation of wild populations, continued commercial demand poses a serious impediment to reintroducing $G$. platynota into the wild.

In addition to over-harvesting, fragmentation and conversion of land to row crop agriculture threaten the integrity of G. platynota habitat. For instance, a large tract of land in Shwe Settaw Wildlife Sanctuary was sold to a development corporation and cleared for agriculture in the late 1990s (Platt et al. 2001a). Although the area was likely devoid of tortoises when sold, the loss of this potential habitat means a decrease in the potential land base available for future reintroductions. On a positive note, numerous observations of tortoises in pastures and agricultural fields surrounding Myaleik Taung indicate that G. platynota can survive in anthropogenic habitats if not subjected to harvesting (Platt et al. 2003).

Under some circumstances, dry season wildfires probably posed a risk to $G$. platynota populations. According to Theobald (1868), "vast numbers perished" during fires deliberately set by hunters. Platt et al. (2001a) found anomalies suggestive of fire injuries on several $G$. platynota, and noted hunters occasionally come across dead tortoises following fires in Shwe Settaw Wildlife Sanctuary. Undoubtedly the risk to tortoises depends on aspects of fire behavior (Platt et al. 2010); fast moving intense headfires are more likely to kill tortoises than slow moving, low intensity ground fires (Platt et al. 2003) in this naturally pyrogenic ecosystem (Stott 1988).

Conservation Measures Taken. - While the subsistence harvest of $G$. platynota and other chelonians is permitted in Myanmar, commercial harvesting is illegal under domestic forestry and fisheries legislation (Platt et al. 2000). Protective legislation is enforced by the Fisheries Department and the Wildlife Conservation Division of the Forest Department. The former does not issue permits for commercial harvesting of turtles and Law 34 provides stiff penalties for those engaged in turtle trading. However, enforcement of existing legislation is often lax and appears largely ineffectual in stemming the illegal flow of chelonians from Myanmar into southern China. Because G. platynota is listed under Appendix II of CITES, this trade is also in clear violation of the convention, which Myanmar signed in 1997 (Platt et al. 2000).

All wildlife is afforded complete protection in wildlife sanctuaries and national parks of Myanmar (Platt et al. 2000); however, enforcement is weak to non-existent in many protected areas and G. platynota has been extirpated from the only two wildlife sanctuaries where it was known to occur. An attempt in 2007 to reintroduce $G$. platynota into Minzontaung Wildlife Sanctuary was unsuccessful; tortoises were poached or simply disappeared within six months of being released (Platt et al.2011). A 2001 proposal by the Forest Department to designate Myaleik Taung as a National Star Tortoise Sanctuary was apparently abandoned after the resident G. platynota population was extirpated by commercial collectors.

Conservation Measures Proposed. - Barring the discovery of hitherto unknown populations, future conservation efforts for $G$. platynota hinge on developing and implementing successful captive breeding (see Captive Husbandry below) and reintroductions programs in Myanmar. Because commercial demand and the likelihood of poaching remain high, reintroductions should only be attempted in protected areas such as wildlife sanctuaries and national parks.

However, it is essential to develop effective anti-poaching measures at these sites before any reintroductions are attempted. The recent disappearance of reintroduced tortoises at Minzontaung Wildlife Sanctuary highlights the need for such protective measures. Additionally, we urge Myanmar authorities to revisit plans to establish a National Star Tortoise Sanctuary at Myaleik Taung. Pre-existing religious beliefs coupled with effective enforcement at this site would probably provide an acceptable level of protection for reintroduced tortoises, making this venture likely to succeed.

In addition to developing effective anti-poaching measures, protected areas within the dry zone are subject 
to livestock grazing, frequent anthropogenic burning, and fuelwood cutting, and any management plan for G. platynota must take these factors into account (Platt et al. 2003). The effect of livestock grazing on tortoises represents a complex interaction between climate, vegetation, forage availability, and grazing intensity that must be evaluated in a site-specific context (Kazmaier et al. 2001). Because livestock compete with tortoises for grass (Oldemeyer 1994), we recommend that grazing be regulated, although not necessarily eliminated, within areas managed for G. platynota.

Uncontrolled fires pose a direct threat to tortoises and therefore fire management must be part of any conservation plan. Rather than attempt to exclude fires from this naturally pyrogenic ecosystem (Stott 1988), it is recommended that low-intensity prescribed burns be conducted annually by sanctuary staff early in the dry season (October-November). Burning at this time will reduce fuel loads and lessen the probability of catastrophic wildfires later in the dry season, and also stimulate the production of forage, particularly grasses for tortoises (Wharton 1966; Landers and Speake 1980; Rabinowitz 1990).

It is also recommended that fuelwood cutting be suspended within protected areas because continued deforestation will undoubtedly lead to soil erosion and degradation of watershed functions. Because inhabitants of surrounding villages often depend on protected areas as a source of wood, development of community forestry programs managed by sanctuary staff are warranted.

Additionally, educational programs in villages surrounding protected areas should be conducted to raise public awareness of tortoise conservation, explain environmental services provided by protected areas, instill general conservation values, and foster a greater appreciation of Myanmar's natural history (Platt et al. 2003).

Finally, it must be stressed that the fate of G.platynota and other wildlife in Myanmar ultimately depends on the ability of authorities to curb the illicit trans-border trade of wildlife into neighboring countries, particularly China and Thailand.

Captive Husbandry. - If housed properly and provided with an adequate diet, $G$. platynota reproduces readily in captivity. In Myanmar, captive breeding colonies are maintained by the Forest Department at the Yadanabon Zoological Gardens in Mandalay, and Minzontaung, Shwe Settaw, and Lawkanandar Wildlife Sanctuaries, with the objective of producing tortoises for eventual release into the wild. Additionally, a Japanese-owned commercial breeding facility in Bagan is raising tortoises for export, although their operating permit requires that a certain percentage of captive-reared offspring be made available to the Forest Department for conservation projects. Captive groups were founded using G. platynota confiscated from the illegal wildlife trade, and in some cases locally collected tortoises. At the time of this writing it is unclear precisely how many tortoises are held at these facilities, but an inspection tour in January 2009 revealed over 300 hatchlings and juveniles in addition to the core group of breeding adults. Captive tortoises at government and private facilities are maintained under semi-natural conditions in spacious outdoor enclosures.

Captive tortoises are fed a diet of locally harvested grasses (Poaceae), water bindweed (Ipomoea sp.), Roselle (Malvaceae), and various fruits. Nests produced by captive $G$. platynota are marked with wooden stakes, and eggs incubated in situ; earlier attempts to artificially incubate eggs were only partially successful (Thanda Swe 2004). During the cool winter season, captives are often buried under straw or dry leaves at night to avoid chilling. Theft of captives has occurred and remains a constant concern at all facilities. To discourage thieves, tortoises are recovered daily from the enclosures, placed in small locked rooms overnight, and closely guarded by watchmen. In the past, this practice led to the excessive handling of juveniles during the cool season when tortoises are normally dormant, and significant mortality resulted (over 30 juveniles in 2006; D. Emmett, pers. obs.). Therefore, alternate means of securing juvenile tortoises from theft should be developed.

Guidelines for captive husbandry of G.platynota outside of Myanmar are provided by Fife (2007). Weather permitting, G. platynota fares well if housed outdoors, but in temperate climates seasonally low temperatures mean that tortoises are likely to spend much time indoors. Hatchling tortoises must be provided with a humid environment to avoid "pyramiding", a condition which occurs when scutes become raised or pyramid-shaped in response to overly dry conditions and improper diet. Hatchlings and juveniles also seem to benefit from heat lamps outfitted with UVB-emitting bulbs. Younger tortoises are best maintained under temperatures ranging from $21^{\circ}$ (night) to $32^{\circ} \mathrm{C}$ (day), while older tortoises tolerate a wider temperature range provided they have ready access to a heated box.

Like other tortoises, G. platynota is prone to respiratory ailments if chilled. Captive G. platynota should be fed daily and offered a varied diet of fresh grasses, vegetables, and fruits. Care should be taken to avoid including oxalate-rich plants in the diet. Excessive protein intake is undesirable, but some protein should be incorporated into the diet. Clean water should be available at all times as dehydration can result in the formation of bladder stones. If available, prickly-pear cactus (Opuntia spp.) is an excellent source of food and water. Geochelone platynota breed readily if properly maintained, and propagation appears most successful when tortoises are kept for at least part of the year in outdoor enclosures. In most regions of North America, Europe, and Japan, seasonally low soil temperatures during the lengthy incubation period preclude successful in-situ incubation of eggs.

Under artificial conditions eggs are best incubated at temperatures between 29 and $32^{\circ} \mathrm{C}$ with humidity levels $>60 \%$. Males and females are produced at lower $\left(29-31^{\circ} \mathrm{C}\right)$ and higher $\left(31-32^{\circ} \mathrm{C}\right)$ incubation temperatures, respectively. An initial cooling period of 30 days at $18^{\circ} \mathrm{C}$ reportedly increases the hatching rate among G. platynota eggs (Fife 2007).

An outbreak of Ranavirus was reported in a captive colony of G. platynota at St. Catherines Island Wildlife Survival Center, Georgia, USA, in 2003. Three of five 
tortoises in the colony became infected; clinical signs included persistent nasal discharge, stomatitis, conjunctivitis, and edema throughout the cervical tissues (Johnson et al. 2004). Intracoelomic fluids were administered and infected tortoises were treated with antimicrobials and antivirals, and soaked daily in warm water (Johnson et al. 2008). Although one female died, the two remaining tortoises responded to supportive care and soon recovered (Johnson et al. 2004). Frogs living within and near the tortoise enclosure were thought to be a reservoir host for infection (Johnson et al. 2004, 2008).

Current Research. - To our knowledge, there is no research involving wild populations of G.platynota underway at this time. Anumber of captive breeding projects in Myanmar are being conducted and monitoring of released animals will be a component of any future reintroduction plan.

Acknowledgments. - We wish to thank Peter Paul van Dijk and John Iverson for supplying critical references. Over the years fieldwork by the authors has been generously supported by the Myanmar Program of the Wildlife Conservation Society, Turtle Survival Alliance, Sabin Family Foundation, and Turtle Conservation Fund. Additional support for SGP was provided by Sul Ross State University. An early draft of this account was improved by the comments of John Iverson and Lewis Medlock.

\section{LITERATURE CITED}

Abreu, R. 1858. Journal of a tour through the Pegu and Martaban Provinces in the suite of Drs. McClelland \& Brandis, successively superintendents of forests, Pegu. Moulmein: T. Whittam, 239 pp.

BLYTH,E. 1863. A collection of sundries from different parts of Burma. Journal of the Asiatic Society of Bengal 32:78-90.

Bourret, R. 1941. Les tortues de l'Indochine. Notes Institut Oceanographique de l'Indochine 38:1-235.

Buhlmann, K.A., Akre, T.S.B., Iverson, J.B., Karapatakis, D., Mittermeier, R.A., GeORGes,A., Rhodin,A.G.J., van DiJK, P.P., AND GibBons, J.W. 2009. A global analysis of tortoise and freshwater turtle distributions with identification of priority conservation areas. Chelonian Conservation and Biology 8(2):116-149.

Compton, J. 2000. An overview of Asian turtle trade. In: van Dijk, P.P., Stuart, B.L., and Rhodin, A.G.J. (Eds.). Asian Turtle Trade: Proceedings of a Workshop on Conservation and Trade of Freshwater Turtles and Tortoises in Asia. Chelonian Research Monographs No. 2, pp. 24-29.

Congdon,J.D.,Dunham,A.E.,ANDVAnLobenSels,R.C.1993.Delayed sexual maturity and demographics of Blanding's turtles (Emydoidea blandingii): implications for conservation and management of longlived organisms. Conservation Biology 7:826-833.

Crumly, C.R. 1982. A cladistics analysis of Geochelone using cranial morphology. Journal of Herpetology 16:215-234.

DAS,I. 1997.Conservation problems of tropicalAsia's most threatened turtles. In: van Abbema, J.(Ed.). Proceedings: Conservation, restoration, and management of tortoises and turtles - An International Conference. New York: New York Turtle and Tortoise Society and Wildlife Conservation Turtle Recovery Program, pp. 295-301.

DAVIs, J.H. 1964. The forests of Burma. Sarracenia 8:1-41.

De Terra, H. 1944. Component geographic factors of the natural regions of Burma. Annals Association of American Geographers
34:67-96.

ERNST,C.H.ANDBARBOUR,R.W.1989.Turtles of the World.Washington, DC: Smithsonian Institution Press, 314 pp.

FAO/UNDP. 1982. Shwesettaw Wildlife Sanctuary: report on a reconnaissance survey and evaluation, June 1982. Rangoon: FAO/UNDP Nature Conservation and National Parks Project, BUR/80/006, Field Report 9/82, 19 pp.

FIFE, J.D. 2007. Star tortoises: the natural history, captive care, and breeding of Geochelone elegans and Geochelone platynota. Turtles of the World Series: Testudinidae: No. 10.

Fritz, U. AND BININDA-EDMONDS, O.R.P. 2007. When genes meet nomenclature: tortoise phylogeny and the shifting concepts of Testudo and Geochelone. Zoology 110:298-307.

Hundley, H.G. 1961. The forest types of Burma. Tropical Ecology 2:48-76.

IVERSON, J. 1992. A Revised Checklist with Distribution Maps of the Turtles of the World. Richmond, IN: Privately printed, $363 \mathrm{pp}$.

JENKINS,M.D.1995. Tortoises and freshwater turtles: the trade in Southeast Asia. Cambridge, U.K.: TRAFFIC International, 48 pp.

Johnson, A.J., Norton, T.M., Wellehan, J.F.X., Pessier, A.P., Spratt, J., Stedman, N.L., AND JACoBson, E.R. 2004. Iridovirus in captive Burmese startortoises (Geocheloneplatynota).Proceedings Association of Reptilian and Amphibian Veterinarians 2004:143-144.

Johnson,A.J.,Pessier,A.P., Wellehan,J.F.X.,Childress, A., Norton, T.M.,Stedman,N.L.,BloOm,D.C.,Belzer,W.,Titus, V.R., Wagner, R., BROOKS, J.W., SPRATT, J., AND JACOBSON, E.R. 2008. Ranavirus infection of free-ranging and captive box turtles and tortoises in the United States. Journal of Wildlife Diseases 44:851-863.

Kazmaier, R.T., Hellgren, E.C., Ruthven, D.C., III, and Synatzske, D.R. 2001. Effects of grazing on the demography and growth of the Texas tortoise. Conservation Biology 15:1091-1101.

KLemens, M.W. and Thorbjarnarson, J.B. 1995. Reptiles as a food resource. Biodiversity and Conservation 4:281-298.

LANDERS, J.L. AND SPEAKE, D.W. 1980. Management needs of sandhill reptiles in southern Georgia.Proceedings Annual Conference Southeastern Association of Fish and Wildlife Agencies 34:515-529.

Le, M., RaXworthy, C.J., McCord, W.P., And Mertz, L. 2006. A molecular phylogeny of tortoises (Testudines: Testudinidae) based on mitochondrial and nuclear genes. Molecular Phylogenetics and Evolution 40:517-531.

Loveridge, A. AND WILliams, E.E. 1957. Revision of the African tortoises and turtles of the suborder Cryptodira. Bulletin of the Museum of Comparative Zoology 115:163-557.

Moll, E.O. 1989. Geochelone platynota. Burmese star tortoise. In: Swingland, I.R. and Klemens, M.K.(Eds.). The Conservation Biology of Tortoises. Occas.Papers IUCNSpecies Survival Commission, No. 5. Gland, Switzerland: IUCN Publ., 115 pp.

Oвsт, F.J. 1986. Turtles, tortoises, and terrapins. Leipzig: Druckerei Fortschritt Erfurt, 230 pp.

OLDEMEYER, J.L. 1994. Livestock grazing and the desert tortoise in the Mojave Desert. In: Bury, R.B. and Germano, D.J. (Eds.). Biology of the North American tortoises. Washington, DC: National Biological Survey, Technical Report Series Fish and Wildlife Service No. 13, pp. 95-103.

Platt, S.G. 1999. A tortoise survey of the Shwe Settaw Wildlife Sanctuary, Myanmar. Report to Wildlife Conservation Society, Bronx, New York, 41 pp.

Platt, S.G. 2001a. An investigation into the conservation status of Kachuga trivittata and other turtles of the upper Ayeyarwady and Dokthawady (Myitnge) rivers, Myanmar. Report to Wildlife Conservation Society, Bronx, New York, 46 pp.

Platt, S.G. 2001b. Further investigation into the conservation status and biology of the star tortoise (Geochelone platynota) at two sites 
in Myanmar. Report to Wildlife Conservation Society, Bronx, New York, $52 \mathrm{pp}$.

PLATT, S.G. 2001c. A training course on the conservation and captive breeding of turtles and tortoises in Myanmar. Shwe Settaw Wildlife Sanctuary, Myanmar. Report to Wildlife Conservation Society, Bronx, New York, 7 pp.

Platt, S.G., Kyaw Moe, Platt, K.P., and Me Me Soe. 2011. An assessment of Shwe Settaw and Minzontaung Wildlife Sanctuaries as reintroduction sites for the critically endangered Geochelone platynota. Report to Wildlife Conservation Society, Bronx, New York. 44 pp.

Platt, S.G.,Liu, H., AND Borg, C.K. 2010. Fire ecology of the Florida box turtle(Terrapene carolina bauri Taylor) in pine rockland forests of the lower Florida Keys. Natural Areas Journal 30:254-260.

Platt,S.G.,SawTunKhaing,WinKoKo,andKalyar.2001a.Atortoise survey of Shwe Settaw Wildlife Sanctuary, Myanmar, with notes on the ecology of Geochelone platynota and Indotestudo elongata. Chelonian Conservation and Biology 4:172-177.

Platt, S.G., Saw Tun Khaing, Win Ko Ko, and Kalyar. 2001b. Distributional notes on the turtles of western Myanmar. Journal of the Bombay Natural History Society 98:117-120.

Platt, S.G., Win Ko Ko, and Kalyar. 2000. Exploitation and conservation status of tortoises and freshwater turtles in Myanmar. In: van Dijk, P.P., Stuart, B.L., and Rhodin, A.G.J.(Eds.). Asian Turtle Trade: Proceedings of a Workshop on Conservation and Trade of Freshwater Turtles and Tortoises in Asia. Chelonian Research Monographs No. 2, pp. 95-100.

Platt, S.G., Win Ko Ko, Lay Lay Khaing, Khin Myo Myo, Thanda Swe, Tint Lwin, and Rainwater, T.R. 2003. Population status and conservation of the critically endangered Burmese star tortoise Geochelone platynota in central Myanmar. Oryx 37:464-471.

Platt, S.G., Win Ko Ko, Lay Lay Khaing, Khin Myo Myo, Thanda Swe, Kalyar, and Rainwater, T.R. 2004. Recent records and comments on the distribution and conservation status of Geochelone platynota (Blyth, 1863) in the dry zone of central Myanmar. Hamadryad 29:128-131.

RABINOWITZ, A. 1990. Fire, dry dipterocarp forest, and the carnivore community in Huai Kha Khaeng Wildlife Sanctuary, Thailand. Natural History Bulletin of the Siam Society 38:99-115.

Roberts, T.D., Matthews, J.M., McMorris, D.S., Parachini, K.E., RAIFORD,W.N., AND TownSEND,C. 1968. Area handbook for Burma. DA Pamphlet No. 550-61. Washington, DC: U.S. Government Printing Office, $375 \mathrm{pp}$.

Robbins, R.G. and Platt, S.G. 2000. First report of Amblyomma clypeolatum Neumann (Acari: Ixodida: Ixodidae) from the Union of Myanmar, with two new records from tortoises. Proceedings of the Entomological Society of Washington 102:225-226.

SEARLE,H.F. 1928. Burma Gazetteer: The Mandalay District, Volume A. Rangoon: Government Printing Office, $178 \mathrm{pp}$.

SмIтн, M.A. 1931. The fauna of British India, including Ceylon and Burma.Reptilia and Amphibia.Vol.1.Loricata,Testudines.London: Taylor and Francis, Ltd., 185 pp.
STAMP, L.D. AND LoRD, L. 1923. The ecology of parts of the riverine tract of Burma. Journal of Ecology 11:129-159.

Sтотт, P. 1988. The forest as Phoenix: towards a biogeography of fire in mainland south east Asia. Geographical Journal 154:337-350.

Thanda Swe. 2004.Autecology of Myanmar star tortoise, Geochelone platynota (Blyth, 1863). Ph.D. Thesis, University of Mandalay, Mandalay, Myanmar.

Thant MyINT-U. 2006. The river of lost footsteps: histories of Burma. New York: Farrar, Straus, and Giroux, 361 pp.

Theobald, W. 1868. Catalogue of the reptiles of British Birma [sic], embracing the provinces of Pegu, Martaban, and Tennasserim: with descriptions of new or little known species. Journal of the Linnean Society (Zoology) 10:4-67.

Thorbjarnarson, J., Lageaux, C.J., Bolze, D., Klemens, M.W., and Meylan, A.B. 2000. Human use of turtles. In: Klemens, M.W. (Ed.). Turtle Conservation. Washington, DC: Smithsonian Institution Press, pp. 33-84.

VANDIJK,P.P. 1993. Myanmarturtles: Reporton a preliminary survey of the Testudines of the Ayeyarwady Basin. Report to Turtle Recovery Program, The World Conservation Union-IUCN/SSC Tortoise and Freshwater Turtle Specialist Group, 34 pp.

VAN DIJK, P.P. 1994. Report on a visit to Myanmar, 18-28 January 1994. Report to Turtle Recovery Program, The World Conservation Union-IUCN/SSC Tortoise and Freshwater Turtle Specialist Group, 23 pp.

VANDIJK,P.P. 1997. Turtle conservation in Myanmar: Past, present, and future. In: van Abbema, J.(Ed.). Proceedings: Conservation, restoration, and management of tortoises and turtles - An International Conference. New York: New York Turtle and Tortoise Society and Wildlife Conservation Turtle Recovery Program, pp. 265-271.

VAN DiJK, P.P., STUART, B.L., AND RHOdIN, A.G.J. (Eds.). 2000. Asian Turtle Trade: Proceedings of aWorkshopon Conservation and Trade of Freshwater Turtles and Tortoises in Asia. Chelonian Research Monographs No. 2, 164 pp.

WharTon, C.H. 1966. Man, fire and wild cattle in north Cambodia. Proceedings Tall Timber Fire Ecology Conference 5:23-65.

Zug, G.H., Htun Win, Thin Thin, ThanZaw Min, Win Zaw Lhon, and KYAW KYAW. 1998. Herpetofauna of the Chattin Wildlife Sanctuary, north-central Myanmar, with preliminary observations of their natural history. Hamadryad 23:111-120.

\section{Citation Format for this Account:}

Platt, S.G., Thanda Swe, Win Ko Ko, Platt, K., Khin Myo Myo, RaInwater, T.R., AND EMmetT, D. 2011. Geochelone platynota (Blyth 1863) - Burmese Star Tortoise, Kye Leik.In: Rhodin,A.G.J., Pritchard, P.C.H., van Dijk, P.P., Saumure, R.A., Buhlmann, K.A., Iverson, J.B., and Mittermeier, R.A. (Eds.). Conservation Biology of Freshwater Turtles and Tortoises: ACompilation Project of the IUCN/ SSC Tortoise and Freshwater Turtle Specialist Group. Chelonian Research Monographs No. 5, pp. 057.1-057.9, doi:10.3854/crm.5.057. platynota.v1.2011, http://www.iucn-tftsg.org/cbftt/. 